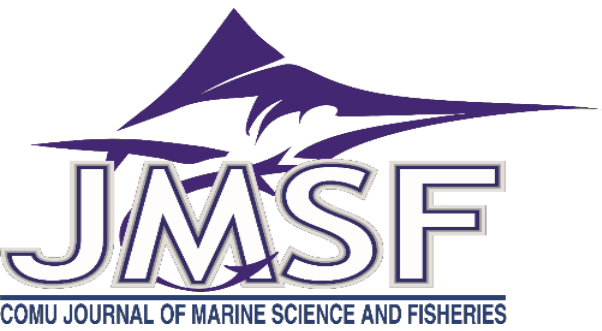

\title{
Biological Aspects of the Brown Ray (Raja miraletus Linnaeus, 1758) in the Saros Bay, the Northern Aegean Sea
}

\author{
Cahide Çiğdem Yığın* , Ali İşmen \\ Çanakkale Onsekiz Mart University, Marine Science and Technology Faculty, 17100, Çanakkale, Turkey, \\ Correspondent: cyigin@hotmail.com \\ Received: 13.04.2021 Accepted: 28.06.2021 \\ Cahide Çiğdem Ylğın: Orcid 0000-0002-8808-2252 \\ Ali İsmen: Orcid 0000-0003-2456-0232
}

How to cite this article: Yı̆̆ın, C.Ç. \& İşmen, A., (2021). Biological aspects of the brown ray, Raja miraletus Linnaeus, 1758 in the Saros Bay, the northern Aegean Sea. COMU J. Mar. Sci. Fish, 4(1): 32-41. DOI: 10.46384/jmsf.915343

Abstract: The present study reports the age, growth, and reproduction parameters of 52 brown rays (Raja miraletus) captured from the Saros Bay (Northern Aegean Sea) between September 2006 -2008. The males and females accounted for $44.2 \%$ and $55.8 \%$ of the sample, respectively. The males measured $10.5-53.5 \mathrm{~cm}$ (disc width, $6.5-32 \mathrm{~cm}$ ) and the females ranged $25.5-47.7 \mathrm{~cm}$ (disc width, $18-30.5 \mathrm{~cm}$ ) in total length (TL). The equations $\mathrm{TW}=0.0017 * \mathrm{TL}^{3.27}$ and $\mathrm{TW}=0.0017 * \mathrm{DW}^{3.38}$ were used to describe the total length-weight and disc width-weight relationships, respectively. The length-at-age data on vertebrae were used to estimate the von Bertalanffy growth equation: $\mathrm{L}_{\infty}=62.43 \mathrm{~cm}, \mathrm{~K}=0.28$ year $^{-1}, \mathrm{t}_{0}=-0.54$ year. The maximum age was found to be 4 years for both the males and females.

Keywords: Raja miraletus, Age, Growth, Reproduction, Saros Bay, Aegean Sea

\section{Saros Körfezi’nde (Kuzey Ege Denizi) Kahverengi Vatozun (Raja miraletus Linnaeus) 1758 Biyolojik Yönleri}

Özet: Bu çalışmada, Kuzey Ege Denizi, Saros Körfezi'nde, Eylül 2006 ve 2008 tarihleri arasında, 52 adet kahverengi vatozun (Raja miraletus) yaş, büyüme ve üremesi çalışılmıştır. Cinsiyet kompozisyonu \% 44,2 erkeklerden ve \%55,8 dişilerden oluşmuştur. Erkeklerin toplam boy aralıkları 10,5'den 53,5 cm'e (disk genişliği, 6,5-32 cm), ve dişilerin 25,5'den 47,7 cm'e (disk genişliğgi, 18-30,5 cm) olarak değişmiştir. Boy-ağırlık ve disk genişliği-ağırlık ilişkileri sırasıyla, $\mathrm{TA}=0,0017 * \mathrm{~TB}^{3,27}$ and $\mathrm{TA}=0,0055^{*} \mathrm{DG}^{3,38}$ olarak tanımlanmıştır. Omur okumalarından boy-yaş verilerine dayanılarak hesaplanan von Bertalanffy denklemindeki büyüme parametreleri: $\mathrm{L}_{\infty}=62,43 \mathrm{~cm}, \mathrm{~K}=0,28 \mathrm{y}_{1} \mathrm{l}^{-1}, \mathrm{t}_{0}=-0,54 \mathrm{y}$ ıl olarak hesaplanmıştır. Maksimum yaşının 4 yıl olduğu tespit edilmiştir.

Anahtar Kelimeler: Raja miraletus, yaş, büyüme, üreme, Saros Körfezi, Ege Denizi

\section{Introduction}

The brown ray, Raja miraletus Linnaeus, 1758 is a small cartilaginous fish found on the continental shelf and distributed from shallower waters down to $530 \mathrm{~m}$ with typical depths of 50-150 m (Relini et al., 1999; Serena, 2005; Hemida et al., 2007). It can inhabit a wide range of substrates, including sandymuddy seabeds to Posidonia meadows (Relini et al. 1999). They are very common in the eastern Atlantic Ocean, Mediterranean Sea, and Western Indian Ocean in which they gather in masses (McEachran et al., 1989; Compagno et al., 1991). R. miraletus is not an intended target at commercial fisheries; however, it is unintentionally captured by demersal trawls, gillnets, trammel nets, and bottom longline fisheries in the North Aegean Sea. Even though it has suffered from increasing fishing pressure, little is known about its life history; therefore, it is reported as "Least Concern" in the IUCN Red List assessments (Cavanagh \& Gibson, 2007; Kadri et al., 2014a) 
Previous research reports data on age, growth, reproductive biology, feeding, and distribution of $R$. miraletus from the Mediterranean - e.g., Tunisia (Capapé \& Quignard 1974, 1977; Kadri et al., 2012; Kadri et al. 2014a; Kadri et al., 2014b; Marongiu et al., 2015), Egypt (Abdel-Aziz, 1987; 1992), Adriatic waters (Zupanovic, 1961; Jardas, 1973; Ungaro, 2004), and Eastern Atlantic (coast of Senegal) (Capapé et al., 2010). There is some data on the morphological characteristics and distribution of $R$. miraletus in Turkish waters, (Torcu \& Aka, 2000; Filiz \& Mater, 2002; Filiz \& Bilge, 2004; Ismen et al., 2007a; İlkyaz et al., 2008; Y1gin \& Ismen, 2009; Gurbet et al., 2013; Akyol et al., 2017; Bilge et al., 2014). Therefore, elucidation of basic life history of this species in Turkish waters is important for developing conservation and management strategies. as previous studies offer no data on this species' age, growth and reproductive biology in the Northern Aegean Sea. Thus, the present study provides data concerning age, growth, and age at sexual maturity of $R$. miraletus in the Saros Bay, the North Aegean Sea.

\section{Material and Methods}

In this study, 23 male and 29 female $R$. miraletus were captured by bottom trawls (with a stretched mesh size of $44 \mathrm{~mm}$ at the cod-end) at depths ranging from 50 - $200 \mathrm{~m}$ in the Northern Aegean Sea (Figure 1). Trawl operations were performed monthly during September 2006 - September 2008. Samples were transferred to the laboratory the same day and total length (TL), disc width (DW), and body weight (W) were measured. The individuals' sexes were determined based on the presence and absence of clasper (Hara et al., 2018). Length-weight relationships were defined by allometric equations (Sparre et al., 1989): $\mathrm{W}=\mathrm{aL}^{\mathrm{b}}$, where $\mathrm{W}$ refers to the total body weight $(\mathrm{g}), \mathrm{L}$ to the total length $(\mathrm{cm})$, and a and $b$ are employed as constants. The Length-weight relationships between sexes were compared using ttests to determine statistical differences. The slopes of the regression equations were corrected to follow a geometric mean regression as defined by Ricker (1973). Two sample t-test was used to test the hypothesis of isometric relationship (H0: slope $=3$; H1: slope $\neq 3$ ) (Zar, 1999).

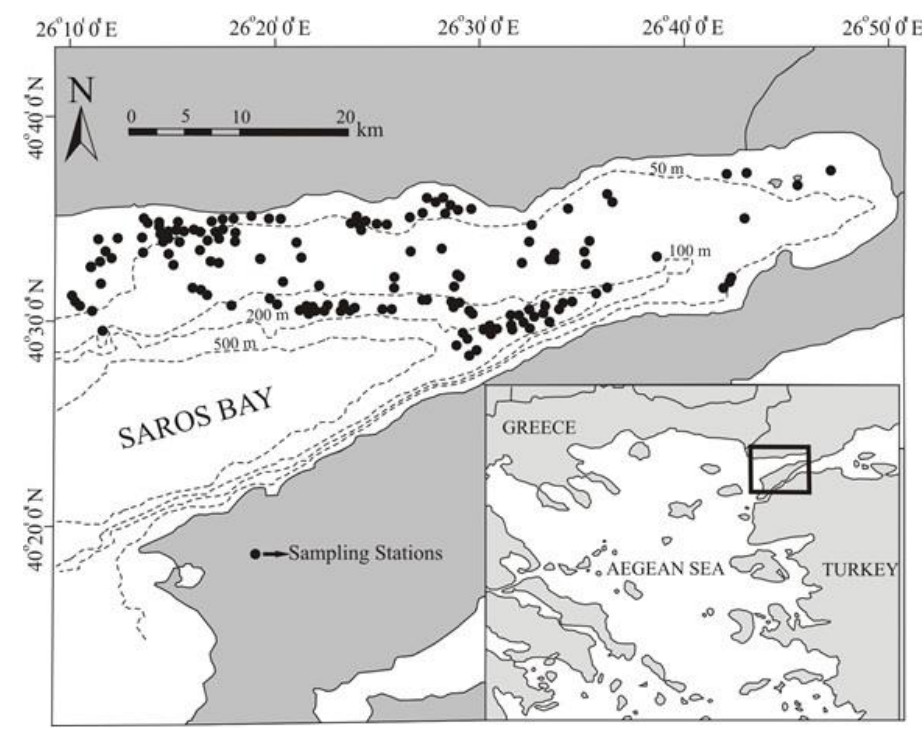

Figure 1. Locations of trawl sampling stations in Saros Bay, the North Aegean Sea.

Age determination was performed by counting the rings in the vertebral centra after usingthe silver nitrate staining method (Kusher et al., 1992; Ismen et al., 2007b; Yeldan et al., 2009; Yigin \& Ismen, 2010). This method briefly included the following steps: Ten vertebrae (located between approximately the $15^{\text {th }}$ and $25^{\text {th }}$ vertebrae) were obtained from the posterior portion of each specimens' body cavity. The vertebrae were prepared for aging by first cleaning and then staining with silver nitrate. The connective tissues were cleaned with 5-25\% sodium hypochloride solution for $1 \mathrm{~h}$. After burning in $88 \%$ formic acid for 2-4 min, the centra surfaces were washed in distilled water for $5 \mathrm{~min}$. They were then stained in $1 \%$ silver nitrate solution for $10-15 \mathrm{~min}$ and exposed to ultraviolet light for $15 \mathrm{~min}$. The obtained sections were rinsed in distilled water and placed in 5\% isopropyl alcohol for $1 \mathrm{~min}$ to eliminate excess material (Schwartz, 1983; Serena et al., 2005). The stained vertebrae were examined with a light microscope (Olympus SZX16). Three maturity stages (immature, maturing and mature) were determined with respect to size, shape and structure of the clasper, vas deferens, and alar thorns for the male individuals and of the ovaries, uteri, and oviductal glands for the females (Table 1) (Zeiner \& Wolf, 1993; Hara et al., 2018). 
Table 1. Characteristics of each maturity stage for male and female Raja miraletus individuals (Zeiner \& Wolf, 1993; Hara et al., 2018)

\begin{tabular}{clcl}
\hline Stage & \multicolumn{1}{c}{ Male } & \multicolumn{1}{c}{ Female } \\
\hline Immature & $\begin{array}{l}\text { Vas deferens uncoiled. Claspers } \\
\text { uncalcified and not reaching posterior } \\
\text { edge of pelvic fin. Alar thornsabsent. }\end{array}$ & $\begin{array}{l}\text { Ovaries small and undeveloped. } \\
\text { Differentiated ova absent. Shell glands } \\
\text { undeveloped. Uteri thin. }\end{array}$ \\
\hline \multirow{3}{*}{ Maturing } & $\begin{array}{l}\text { Vas deferens coiling. Claspers extending } \\
\text { to posterior edge of pelvic fin and } \\
\text { partially calcified. Alar thorns developing }\end{array}$ & $\begin{array}{l}\text { Ovaries enlarging and differentiating. } \\
\text { Small, whitish ova distinguishable. Shell } \\
\text { gland uteri enlarging. }\end{array}$ \\
\hline Mature & $\begin{array}{l}\text { Vas deferens almost completely coiled. } \\
\text { Claspers fully calcified. Alar thorns fully } \\
\text { grown. }\end{array}$ & $\begin{array}{l}\text { Ova fully developed. Shell glands large } \\
\text { and heart-shaped. Uteri thick and fully } \\
\text { developed }\end{array}$ \\
\hline
\end{tabular}

The growth was calculated by the von Bertalanffy growth equation (Beverton \& Holt, 1957): $\mathrm{L}_{t}=\mathrm{L}_{\infty}(1-$ $\left.\mathrm{e}^{-\mathrm{K}(\mathrm{t}-\mathrm{to})}\right)$, where $\mathrm{L}_{\infty}$ signifies the asymptotic total length, $L_{t}$ the total length at age $t, K$ the growth curvature parameter, and $\mathrm{t}_{0}$ the theoretical age of fish with zero total length. The growth parameters were estimated by the nonlinear method employing a software package, (FISAT; FAO-ICLARM Stock Assessment Tools) (Sparre et al., 1989). The gonadosomatic index (GSI) was assessed monthly by the equation: GSI = (gonad weight/gonad-free fish weight $* 100$. Oocytes were removed from the ovaries and measured and weighted to the nearest gram. The diameter of oocytes $\left(\mathrm{D}_{0}, \mathrm{~cm}\right)$ were measured to the nearest centimeter. The total weight of each oocytes
$\left(\mathrm{W}_{0}, \mathrm{~g}\right)$ were weighed to the nearest $0.01 \mathrm{~g}$. The oocyte diameter-weight relationships were calculated for $R$. miraletus females (Yigin \& Ismen, 2013).

\section{Results}

\section{Morphological measurements}

The TL ranged between 10.5 and $53.5 \mathrm{~cm}$ (DW $6.5-32 \mathrm{~cm})$ for the males $(\mathrm{n}=23)$ and between 25.5 and $47.7 \mathrm{~cm}$ (DW 18-30.5 cm) for the females $(\mathrm{n}=29)$ (Figure 2). A sex-based assessment of the relationship between TL-TW and DW-TW is given in Figure 3. The differences in the TL-TW and DW-TW relationships between the males and females were not found to be statistically significant $(\mathrm{P}>0.05)$.

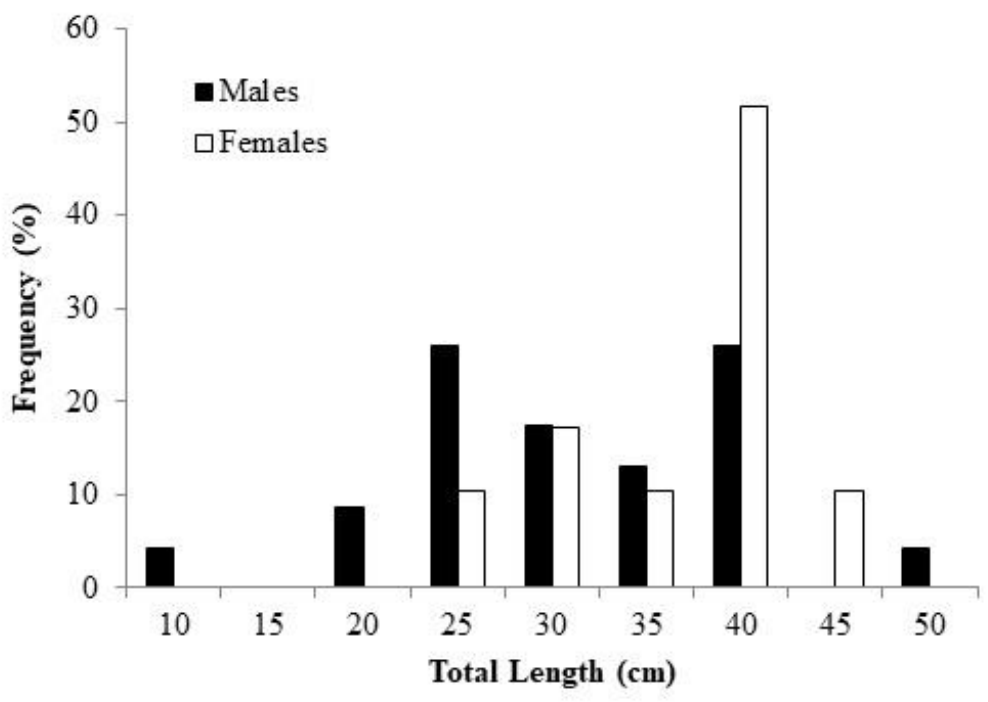

Figure 2. Sex-based length-frequency distribution of the brown ray, in Saros Bay, North Aegean Sea. 

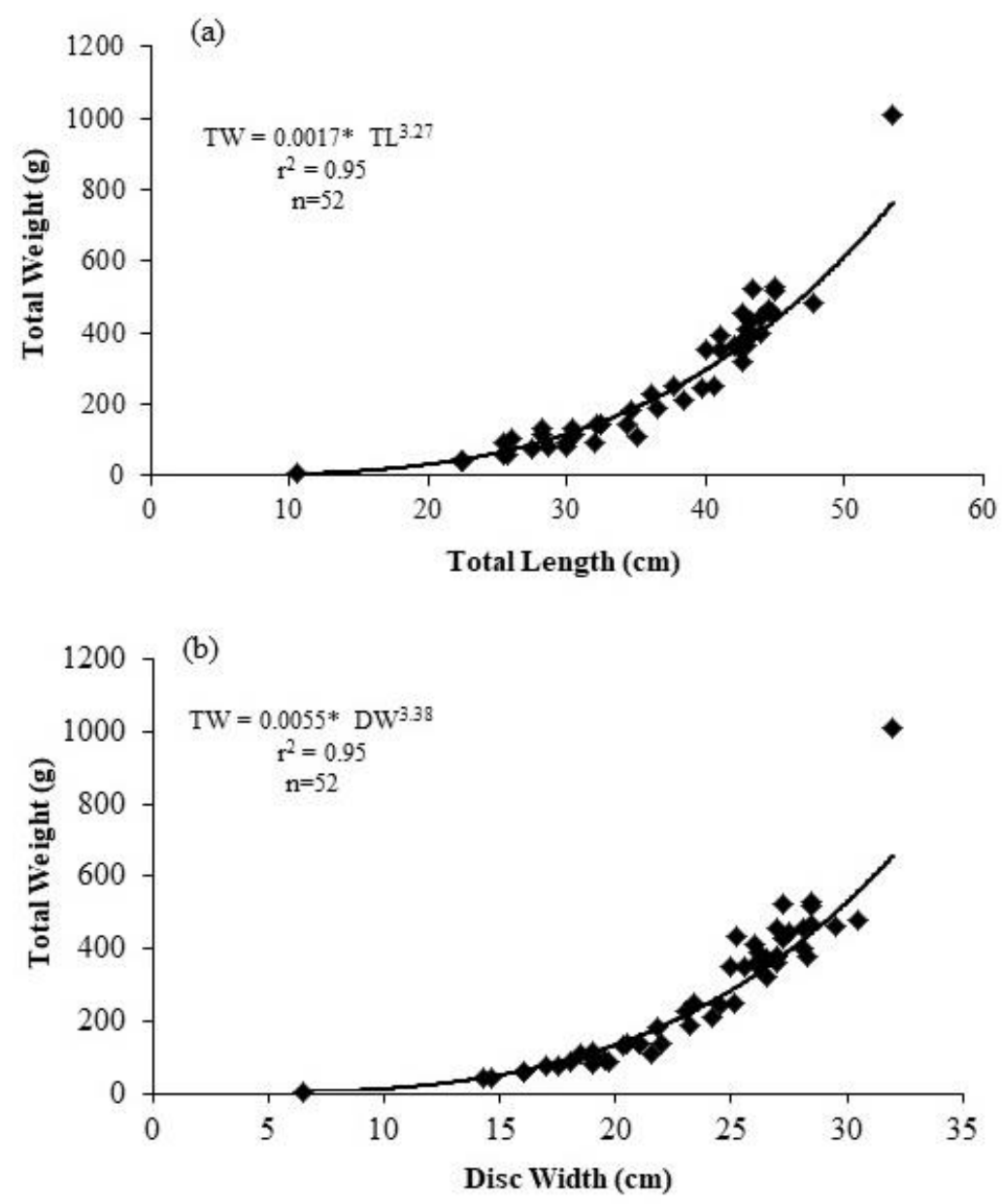

Figure 3. (a) Total length-weight and (b) disc width-weight relationships of $R$. miraletus, (both sexes combined).

\section{Age and growth}

Age distribution of the males and females ranged from 0-4 and 1-4 years, respectively. The dominant mode for ages were 2-3 years for the males and 3 for the females, (Table 2). Growth-in-length of the males, females, and both sexes combined, are given in Table 3.

Table 2. Mean length $(\mathrm{cm})$ in each age group of brown ray, $R$. miraletus

\begin{tabular}{llll}
\hline Age & N & Range $(\mathbf{c m})$ & Mean Length $(\mathbf{c m})$ \\
\hline 0 & 1 & 10.5 & $10.5( \pm 0.000)$ \\
1 & 5 & $22.4-25.7$ & $24.3( \pm 0.753)$ \\
2 & 15 & $26.0-36.5$ & $30.6( \pm 0.713)$ \\
3 & 21 & $35.0-43.4$ & $41.1( \pm 0.558)$ \\
4 & 8 & $44.0-47.7$ & $44.9( \pm 0.418)$ \\
\hline
\end{tabular}

Table 3. von Bertalanffy growth parameters of brown ray, $R$. miraletus

\begin{tabular}{llll}
\hline Sex & $\mathbf{L}_{\infty}(\mathbf{c m})$ & $\mathbf{K}\left(\right.$ year $\left.^{-1}\right)$ & to $($ year $)$ \\
\hline Males & 59.75 & 0.32 & -0.58 \\
Females & 58.50 & 0.34 & -0.50 \\
Combined & 62.43 & 0.28 & -0.54 \\
\hline
\end{tabular}




\section{Gonadosomatic Index (GSI) and Maturity}

Figure 4 shows monthly changes in the mean GSI values of all samples. The GSI values for females are relatively high in March, August and November. Figure 5 presents the percentage of each individual's gonadal development stage. Findings indicated that
$32 \%$ of eggs were immature (I), $40 \%$ maturing (II), and $28 \%$ mature (III). Data on maturity stages suggested that spawning occurs between February October (Figure 5). Based on GSI values and maturity stages of eggs, $R$. miraletus is expected to have a year-round spawning period with a peak in the spring and summer.

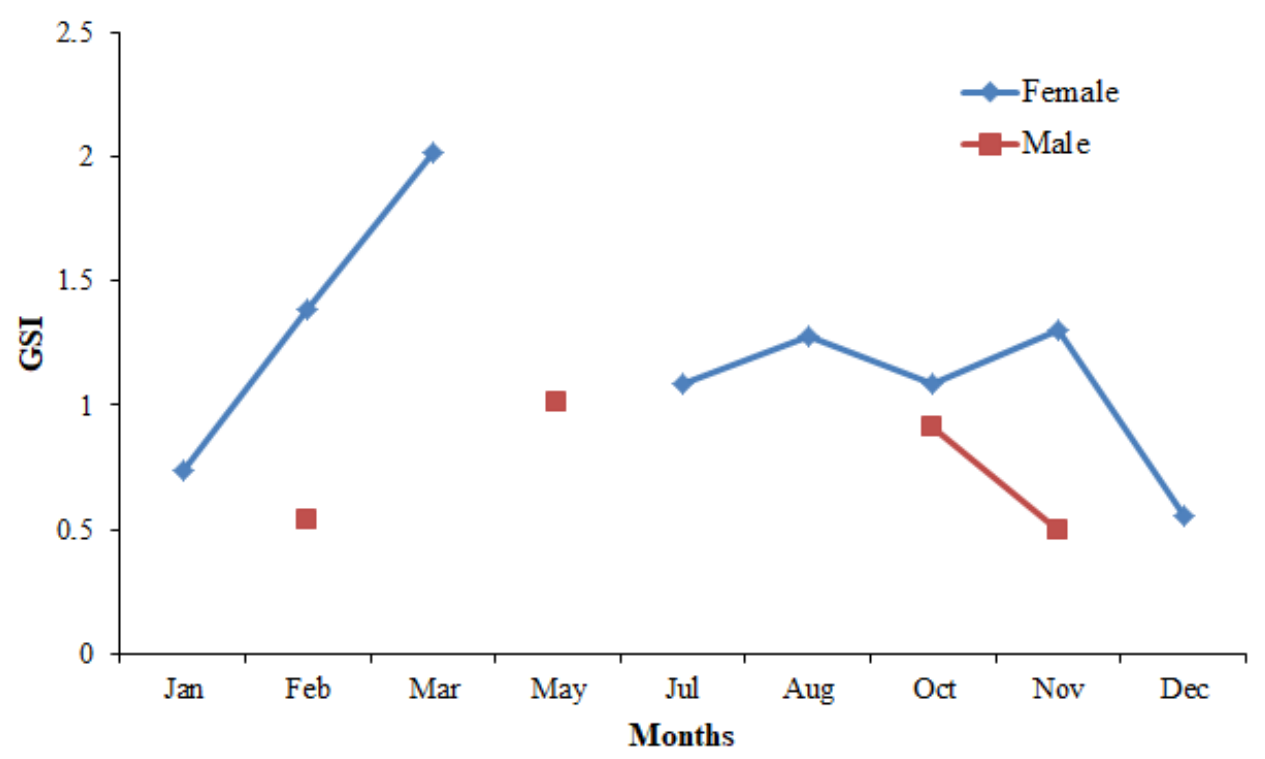

Figure 4. Gonadosomatic index (GSI) values of $R$. miraletus.

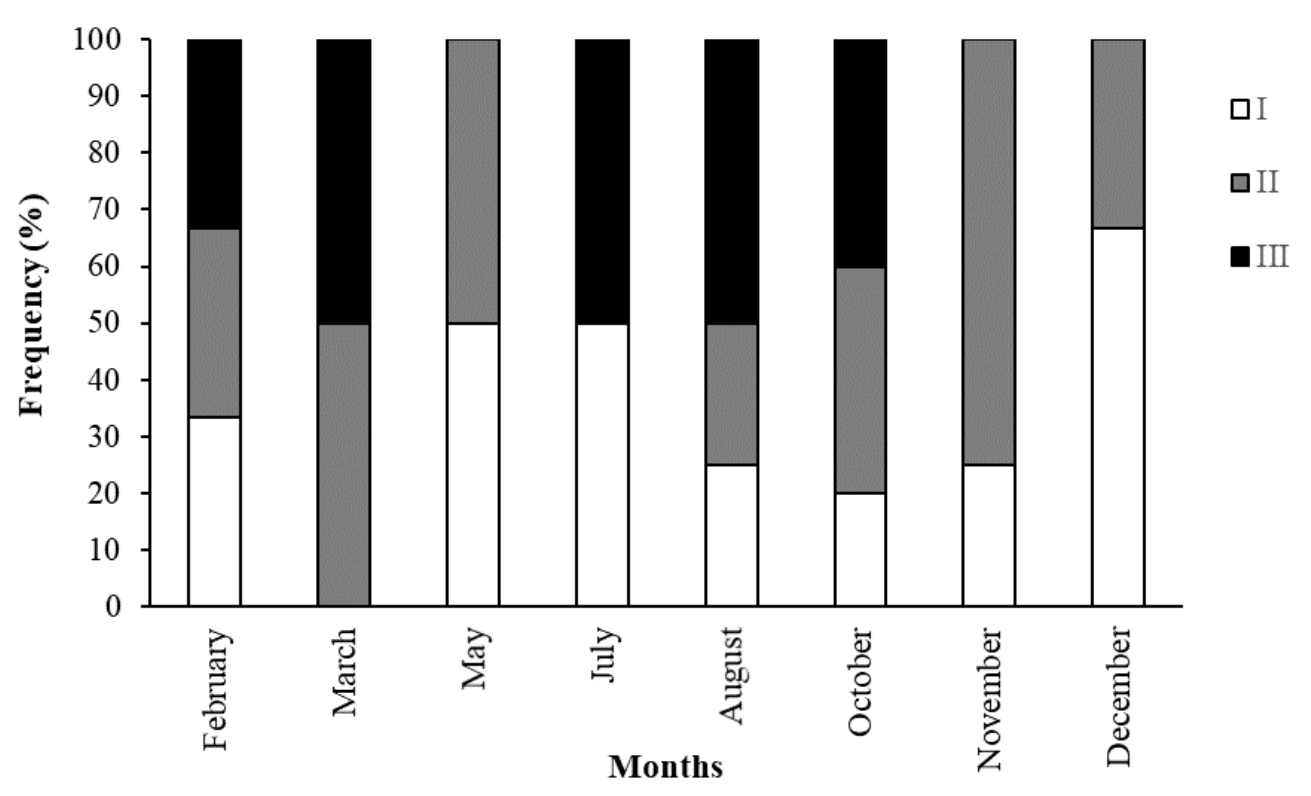

Figure 5. Monthly variations of maturity stages in R. miraletus females (I: immature; II: maturing; III: mature).

Figure 6 shows a strong relationship between oocyte diameter $\left(D_{0}\right)$ and weight $\left(\mathrm{W}_{0}\right)$. A higher variation in oocyte weight was observed for oocytes larger than $0.6 \mathrm{~cm}$.
Two different phases in clasper growth was detected. An abrupt change in the clasper length-total length relationship begins at $\sim 37.7 \mathrm{~cm}$ TL (Figure 7). 


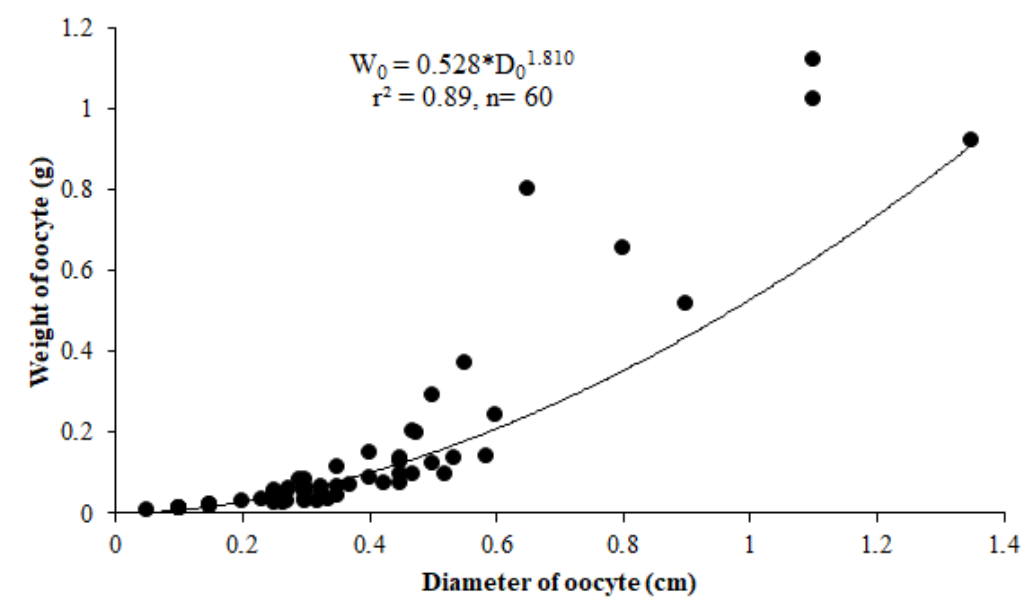

Figure 6. Diameter-weight relationship of oocytes for female $R$. miraletus.

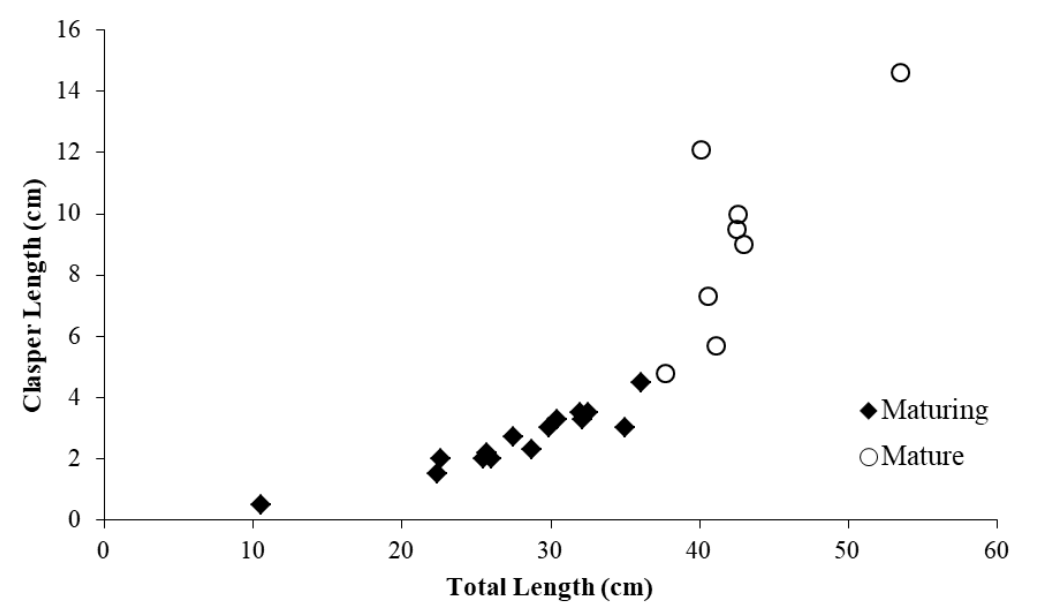

Figure 7. Relative growth of claspers in males.

\section{Discussion}

In this study, meristic measurements of the brown ray were similar to those reported from other studies. The specimens collected from the Gulf of Gabès (Kadri et al., 2014b) ranged from $13.5-58 \mathrm{~cm}$ in total length, $8.5-37 \mathrm{~cm}$ in disc width, and 7 to $980 \mathrm{~g}$ in weight. Capapé and Quignard (1974) reported 32-33 $\mathrm{cm}$ disc width and $54-57 \mathrm{~cm}$ total length for male and female brown rays, respectively, with weights ranging from 151 - $1338 \mathrm{~g}$. Ungaro (2004) found that Total length (TL) ranged from $16.5-51.0 \mathrm{~cm}$ and $15.0-49.5 \mathrm{~cm}$ for females and males, respectively, and the weight for $R$. miraletus to vary between 20 $750 \mathrm{~g}$ in the southern Adriatic basin. In Senegale coasts Capapé et al. (2007) Reported that the weight for $R$. miraletus was $1205-1336 \mathrm{~g}$.

Ungaro (2004) reported a positive allometric growth pattern for $R$. miraletus from the Southern Adriatic basin. Kadri et al. (2014b) estimated the bvalues as 3.38 and 3.33 for the female and male brown rays, respectively, in the Gulf of Gabès. Establisment of the weight-length relationships allow estimation of condition factors and geographical comparison of life histories, and therefore, is critical for fisheries ecology and stock assessment (Petrakis \& Stergiou, 1995; Gonçalves et al., 1997; Froese \& Pauly, 2004).

The studied individuals' growth model suggests that males are capable of reaching a larger asymptotic length $(59.75 \mathrm{~cm})$ than females $(58.50 \mathrm{~cm})$. The von Bertalanffy growth model produced an $\mathrm{L}_{\infty}$ of 62.43 $\mathrm{cm}$ for both sexes. The age and growth rates for the male and female $R$. miraletus reported in this study differed slightly from those given in the previous research. Kadri et al. (2012) and Abdel-Aziz (1992) reported a higher growth rate $k$ for male brown rays than for the females in the Gulf of Gabès and on the Egyptian Mediterranean coasts. The estimated von Bertalanffy growth parameters of $R$. miraletus in different areas are given in Table 4 . The differences in growth model parameters between the present research and previous studies may result from several factors, such as sampling method, location, and age 
classes included in the models (Neer \& Thompson, 2005; Yigin \& Ismen, 2012). Although $R$. miraletus males attain larger sizes than females, this difference between sexes were not significant $(p>0.05)$. Similarly, previous studies reported a low degree of sexual dimorphism in several skate species (Frisk \& Miller, 2006; Natanson et al., 2007; Sulikowski et al., 2005; Hara et al., 2018). In addition, skate species are known to exhibit single oviparity or they can simultaneously carry two egg capsules (Wyffels, 2009; Hara et al., 2018). Developing large embryos may not necessarily require a large body size in $R$. miraletus and this may explain similar body sizes between males and females and lower degree of sexual dimorphism observed in the present study.

Table 4. Region-based comparison of von Bertalanffy growth parameters for R. miraletus.

\begin{tabular}{llllll}
\hline \multicolumn{1}{c}{ Region } & Sex & $\mathbf{L}_{\infty}(\mathbf{c m})$ & K $\left(\right.$ year $\left.^{-1}\right)$ & to $_{\text {(year) }}$ & Source \\
\hline Egyptian & F & 69.2 & 0.18 & 0.11 & \multirow{2}{*}{ Abdel-Aziz (1992) } \\
Mediterranean Coasts & M & 67.0 & 0.22 & 1.01 & \\
\hline \multirow{2}{*}{ Gulf of Gabès } & F & 91.92 & 0.17 & 0.25 & \multirow{2}{*}{ Kadri et al. (2012) } \\
\hline Saros Bay, & M & 87.87 & 0.19 & 0.50 & \\
North Aegean Sea & F & 59.75 & 0.32 & -0.58 & \multirow{2}{*}{ Present study } \\
\hline
\end{tabular}

The GSI of $R$. miraletus were reported to vary between females and males, which is associated with the production of countless large and heavy yolky vitellogenic follicles and incessant reproductive activity throughout the year (Capapé et al., 2007). Hence, the GSI values for males and females showed monthly changes during the year. Similar patterns were reported for $R$. miraletus from the Senegal coasts (Capapé et al., 2010) and the Gulf of Gabès (Kadri et al., 2012), for Raja clavata from the Tunisian coast (Capapé, 1979), and for Atlantoraja cyclophora from the SW Atlantic Ocean (Oddone \& Velasco, 2006; Oddone et al., 2008a). Fluctuating GSI values throughout the year indicate continuous reproductive activity for both male and female $R$. miraletus. . Likewise, the Rio skate, Rioraja agassizi, in Southeastern Brazil showed variations in testicular lobule diameters and mature vitellogenic follicle diameters for males and females, respectively (Oddone et al., 2007), Seasonal GSI changes typical of oviparous species were also reported for other species, such as Scyliorhinus canicula from the northern coast of Tunisia (Capapé, 1977), Psammobatis extenta in the Southwestren Atlantic (Braccini \& Chiaramonte, 2002), and Raja undulata in Southern Portugal (Coelho \& Erzini, 2006). Although oocyte diameter and oocyte weight relationship has been reported for other chondrichthyes species in earlier studies (Oddone \& Vooren, 2005; Demirhan \& Seyhan, 2006; Oddone et al., 2008b; Kousteni \& Megalofonou, 2011; Kadri et al., 2014) this study reports such relationship for $R$. miraletus for the first time.

Currently there is limited information on many aspects of the life history of $R$. miraletus, such as stock structure, mortality rates, spawning grounds and vertical distributions to develop successful management plans for $R$. miraletus populations. The present research provides the first data on age and growth estimates for brown rays in the Saros Bay. The brown rays exhibit similarities to other elasmobranchs with respect to their relatively longer life, lower fecundity, and older age at sexual maturity. The present work will be an important reference for future studies on age validation, breeding season reproductive cycle, and growth patterns of $R$. miraletus.

\section{Acknowledgments}

This study is a part of a more comprehensive study supported by the Office of Scientific Projects at Çanakkale Onsekiz Mart University (Project Number: 200603) and TUBITAK (The Scientific and Technological Research Council of Turkey) (Project Number: 106Y035). The authors would like to thank the crew of the trawl vessel Şahin Reis as well as all the scientific staff who assisted in the fieldwork and the laboratory.

\section{Conflict of Interests}

The author declares no conflict of interest.

\section{Author contribution}

A. İşmen and C.Ç.Yı̆̆ın planned and designed the research. A. İșmen and C.C.Y.Y̆ı̆ın performed the sample collection and analysis. C.C.Yığın contributed in writing the manuscript. All authors read and approved the final manuscript.

\section{References}

Abdel-Aziz, S.H., Ezzat, A, \& Hussein, M. (1987). Sexuality, reproduction and fecundity of Raja miraletus (L) from the Mediterranean waters off Alexandria. Bulletin of the Institute of Oceanography and Fisheries, 13, 119-32. 
Abdel-Aziz, S.H. (1992). The use of vertebral rings of the brown ray Raja miraletus (Linnaeus 1758) off the Egyptian Mediterranean coast for estimation of age and growth. Cybium, 16, 12132.

Akyol, O., Demir Sağlam, Y., \& Ceyhan, T. (2017). A collected work on length-weight relationships of fish species in the Aegean Sea. Ege Journal of Fisheries and Aquatic Sciences, 34(2), 235-247. doi: 10.12714/egejfas.2017.34.2.16

Beverton, R.J., \& Holt, S.J. (1957). On the dynamics of exploited fish populations. Fisheries Investigation Series 2, 19, UK Ministry of Agriculture. Fisheries and Food, London, UK.

Bilge, G., Yapıcı, S., Filiz, H., \& Cerim, H. (2014). Weight-length relations for 103 fish species from the southern Aegean Sea, Turkey. Acta Ichthyologica et Piscatoria, 44 (3), 263-269. doi: 10.3750/AIP2014.44.3.11

Braccini, J.M., \& Chiaramonte, G.E. (2002). Reproductive biology of Psammobatis extenta. J Journal of Fish Biology, 61, 272-288. doi: 10.1111/j.1095-8649.2002.tb01752.x

Capapé, C, \& Quignard, J.P. (1974). Contribution à la biologie des Rajidæ des côtes tunisiennes. I. Raja miraletus Linné 1758: Répartition géographique et bathymétrique, sexualité, reproduction, fécondité. Archives de l'Institut Pasteur de Tunis, $51,39-60$.

Capapé, C. (1977). Observations sur le régime alimentaire de quelques Raies des côtes tunisiennes. Rapport de la Commission Internationale pour la Mer Méditerranée, 24, 99100.

Capapé, C, \& Quignard, J.P. (1977). "Contribución a la biologie des Rajidae des cotes tunisiennes. 6. Raja asterias Delaroche, 1809 Régime alimentaire." Bulletin de l'Institut national scientifique et technique d'océanographie et de pêche, 4 (2-4), 319-332.

Capapé, C. (1979). La torpille marbrée, Torpedo marmorata Risso, 1810 (Pisces, Rajiformes) des côtes tunisiennes: nouvelles données sur l'écologie et la biologie de la reproduction de l'espèce, avec une comparaison entre les populations méditerranéennes et atlantiques. Annales des sciences naturelles Zoologie, Paris 1, 79-97.

Capapé, C., Diatta, Y., Seck, A.A., \& Guélorget, O. (2007). Aspects of the reproductive biology of the brown ray Raja miraletus (Chondrichthyes: Rajidae) from the coast of Senegal (Eastern Tropical Atlantic). Cahiers de Biologie Marine, $48,169-78$.
Capapé, C., Diatta, Y., Ndiaye, P., Reynaud, C., \& Oddone, M.C. (2010). New biological data on the brown ray, Raja miraletus (Chondrichthyes: Rajidae), off the coast of Senegal (eastern tropical Atlantic). Ciencias Marinas, 36(3), 301-309. doi: 10.7773/cm.v36i3.1707

Cavanagh, R.D., \& Gibson, C. (2007). Overview of the Conservation Status of Cartilaginous fishes (Chondrichthyans) in the Mediterranean Sea. IUCN, Gland Switzerland and Malaga, Spain vi + $42 \mathrm{pp}$.

Cherif, M., Zarrad, R., Gharbi, H., Missaouf, H., \& Jarboui, O. (2007). Some biological parameters of the red mullet, Mullus barbatus L., 1758, from the Gulf of Tunis. Acta Adriatica, 48, 131-144. doi: 597.582.6: 591.16 (611)(26.04)

Coelho, R., \& Erzini, K. (2006). Reproductive biology of the undulate ray, Raja undulata, from the South coast of Portugal. Fisheries Research, 81, 80-85. doi: 10.1016/j.fishres.2006.05.017

Compagno, L.J.V., Ebert, D.A., \& Cowley, P.D. (1991). Distribution of offshore demersal cartilaginous fishes (Class Chondrichthyes) off the west coast of southern Africa, with notes on their systematics. South African Journal of Marine Science, 11, 43-139. doi: $10.2989 / 025776191784287664$

Filiz, H., \& Mater, S. (2002). A Preliminary Study on Length-Weight Relationships for Seven Elasmobranch Species from North Aegean Sea, Turkey. Ege Journal of Fisheries and Aquatic Sciences, 19(3-4), 401-409.

Filiz, H, \& Bilge, G. (2004). Length-weight relationships of 24 fish species from the North Aegean Sea, Turkey. Short communication. Journal of Applied Ichthyology, 20, 431-32. doi: 10.1111/j.1439-0426.2004.00582.x

Fontana, A. (1969). Etude de la maturité sexuelle des sardinelles, Sardinella eba (Val.) et Sardinella aurita (C. et V.) de la région de Pointe Noire (A study of the sexual maturity of the sardinelles, Sardinella eba (Val.) and Sardinella aurita (C. and V.) in the Black Cap Area). Cah. ORSTOM. Sér. Océanogr., 7(2), $101-114$.

Frisk, M.G., \& Miller, T.J. (2006). Age, growth, and latitudinal patterns of two Rajidae species in the northwestern Atlantic: little skate (Leucoraja erinacea) and winter skate (Leucoraja ocellata). Canadian Journal of Fisheries and Aquatic Sciences, 63 (5), 1078-1091. doi: 10.1139/f06005

Froese, R., \& Pauly, D. (Eds) (2004). FishBase. World Wide Web electronic publication, http://www.fishbase.org (last accessed:1 March 2004). 
Gonçalves, J.M.S., Bentes, L., Lino, P.G., Riberio, J., Canário, A.V.M., \& Erzini, K. (1997). Weightlength relationships for selected fish species of the small-scale demersal fisheries of the south and south-west coast of Portugal. Fisheries Research, 30 (3), 253-256. doi: 10.1016/S01657836(96)00569-3

Gurbet, R., Akyol, O., Yalcın, E., \& Ozaydın, O. (2013). Discards in bottom trawl fishery in the Aegean Sea (Izmir Bay, Turkey). Journal of Applied Ichthyology, 29, 1269-1274. doi: 10.1111/jai.12243

Hara, K., Furumitsu, K., Aoshima, T., Kanehara, H., \& Yamaguchi, A. (2018). Age, growth, and age at sexual maturity of the commercially landed skate species, Dipturus chinensis (Basilewsky, 1855), in the northern East China Sea. Journal of Applied Ichthyology, 34, 66-72. doi: 10.1111/jai.13575

Hemida, F., Sergouas, W., \& Seridji, R. (2007). Analyse des données morphométriques de quelques espèces du genre Raja Linnaeus, 1758, dans le bassin algérien. Rapp. Comm. Int. Explor. Sci. Mer Médit. 38: 497.

İlkyaz, A.T., Metin, G., Soykan, O., \& Kinacigil, H.T. (2008). Length-weight relationship of 62 fish species from the Central Aegean Sea, Turkey. Journal of Applied Ichthyology, 24, 699-702. doi: 10.1111/j.1439-0426.2008.01167.x

Ismen, A., Özen, Ö., Altinağaç, U., Özekinci, U., \& Ayaz, A. (2007a). Weight-Length Relationships of 63 Fish Species in Saros Bay, Turkey. Journal of Applied Ichthyology, 23, 707-708. doi: 10.1111/j.1439-0426.2007.00872.x

Ismen, A., Yigin, C.C., \& Ismen, P. (2007b). Age, growth, reproductivebiology and feed of the common guitarfish (Rhinobatos rhinobatos Linnaeus, 1758) in_Iskenderun Bay, the eastern Mediterranean Sea. Fisheries Research, 84, 263269. doi: 10.1016/j.fishres.2006.12.002

Ismen, A., Özekinci, U., Özen, Ö., Ayaz, A., Altınağaç, U., Yığın, C.Ç., Ayyıldız, H., Cengiz, Ö., Arslan, M., Ormancı, H.B., Çakır, F., Öz, M.İ. (2010). Saroz Körfezi (Kuzey Ege Denizi) Demersal Balıklarının Biyo-Ekolojisi ve Populasyon Dinamiğinin Belirlenmesi. Proje No: 106Y035, Ankara, 358p.

Jardas, I. (1973). A contribution to our knowledge of thornback ray (Raja clavata L.) and brown ray (Raja miraletus L.) in the Adriatic. Acta Adriatica, 15, 1-42.

Kadri, H., Marouani, S., Saïdi, B., Bradai, M.N., Ghorbel, M., Bouaïn, A., \& Morize, E. (2012). Age, growth and reproduction of Raja miraletus (Linnaeus, 1758) (Chondrichthyes: Rajidae) of the Gulf of Gabès (Tunisia, Central
Mediterranean Sea). Marine Biology Research, 8(4), 388-396. doi: $10.1080 / 17451000.2011 .619546$

Kadri, H., Marouani, S., Bradai, M.N., \& Bouain, A. (2014a). Food habits of the brown ray Raja miraletus (Chondrichthyes: Rajidae) from the Gulf of Gabès (Tunisia). Marine Biology Research, $10 \quad$ (4), 426-434. doi: 10.1080/17451000.2013.797583

Kadri, H., Marouani, S., Bradai, M.N., Bouain, A., \& Morize, E. (2014b). Distribution and morphometric characters of the Mediterranean Brown ray, Raja miraletus (Chondrichthyes: Rajidae) in the Gulf of Gabes (Tunisia, Central Mediterranean). Ajaf Science PG 2(2), 45-50.

Kusher, D.I., Smith, S.E., \& Cailliet, G.M. (1992). Validated age and growth of the leopard shark, Triakis semifasciata, with comments on reproduction. Environmetal Biology of Fishes, 35, 187-203. doi: 10.1007/BF00002193

Marongiu, M.F., Porcu, C., Bellodi, A., Cuccu, D., Mulas, A., \& Follesa, M.C. (2015). Oviducal gland Microstructure of Raja miraletus and Dipturus oxyrinchus (Elasmobranchii, Rajidae). Journal of Morphology, 276, 1392-1403. doi: 10.1002/jmor.20426

McEachran, J.D., Seret, B., \& Miyake, T. (1989). Morphological variation within Raja miraletus and status of Raja ocellifera (Chondrichthyes, Rajoidei). Copeia 1989 (3), 629-641.

Mellinger, J. (1989). Reproduction et développement des Chondrichthyens. Oceánis 15, 283-303. doi: $10.2307 / 1445490$

Natanson, L.J., Sulikowski, J.A., Kneebone, J.R., \& Tsang, P.C. (2007). Age and growth estimates for the smooth skate, Malacoraja senta, in the Gulf of Maine. In: Ebert D.A., Sulikowski J.A. (eds) Biology of Skates. Developments in Environmental Biology of Fishes 27(27), Springer, Dordrecht. doi: 10.1007/978-1-40209703-4_14

Neer, J.A., \& Thompson, B.A. (2005). Life history of the cownose ray, Rhinoptera bonasus, in the northern Gulf of Mexico, with comments on geographic variability in life history traits. Environmetal Biology of Fishes, 73, 321-331. doi: 10.1007/s10641-005-2136-5

Oddone, M.C., \& Velasco, G. (2006). Relationship between liver weight, body size and reproductive activity in Atlantoraja cyclophora (Elasmobranchii: Rajidae: Arhynchobatinae) in oceanic waters off Riogrande do Sul, Brazil. Neotropical Biology and Conservation, 1: 12-16.

Oddone, M.C., Norbis, W., Mancini, P.L., \& Amorim, A.F. (2008). Sexual development and 
reproductive cycle of Atlantoraja cyclophora (Regan 1903) (Chondrichthyes: Rajidae: Arhynchobatidae) in southeastern Brazil. Acta Adriatica, 49, 73-87. doi: 597.35:591.16 (261.2) (81)

Oddone, M.C., Amorim, A.F., Mancini, P.L., Norbis, W., \& Velazco, G. (2007). The reproductive biology and the cycle of Rioraja agassizi (Müller and Henle 1841) (Chondrichthyes: Rajidae) in southeastern Brazil, SW Atlantic Ocean. Scientia Marina, 71, 593-604. doi: 10.3989/scimar.2007.71n3593

Petrakis, G, \& Stergiou, K.I. (1995). Weight-length relationships for 33 fish species in Greek waters. Fisheries Research, 21, 465-469. doi: 10.1016/0165-7836(94)00294-7

Piñeiro, C., \& Sainza, M. (2003). Age estimation, growth and maturity of the European hake, Merluccius merluccius (Linnaeus, 1758) from Iberian Atlantic waters. ICES Journal of Marine Science, 60, 1086-1102. doi: 10.1016/S10543139(03)00086-9

Relini, G., Bertra, N.D.J., \& Zamboni, A. (1999). Synthesis of the knowledge on bottom fishery resources in Central Mediterranean (Italy and Corsica). Biologia Marina Mediterraneanea, 6, 1869.

Ricker, W.E. (1973). Linear regressions in fishery research. Journal of the Fisheries Research Board of Canada, 30, 409-434.

Schwartz, F.J. (1983). Sharking ageing methods and age estimation ofscolloped hammerhead, Sphyma lewini, and dusk, Carcharhinus obscurus, sharks based on vertebral ring counts. NOAA Technical Report NMFS 8, Seattle, pp. 167-174.

Serena, F. (2005). Field Identification Guide to the Sharks and Rays of the Mediterranean and Black Sea. In: FAO Species Identification Guides for Fishery Purposes, FAO, Rome. 136 pp.

Serena, F., Barone, M., Mancusi, C., \& Abella, A.J. (2005). Reproductive Biology, Growth and Feeding Habits of Raja asterias Delaroche,1809, From the North Tyrrhenian and South Ligurian Sea (Italy), with some notes on trends in landings. ICES Annual Science Conference; Theme Session on Elasmobranch Fisheries Science, 20-24 September 2005. CM 2005/N:12.

Sparre, P., Ursin, E., \& Venema, S.C. (1989). Introduction to tropical fish stock assesment. Part I. Manual FAO Fisheries Technical Paper, 306/1. Rome: FAO. 337 pages

Sulikowski, J.A., Kneebone, J., \& Elzey, S. (2005). Age and growth estimates of the thorny skate
(Amblyraja radiata) in the western Gulf of Maine. Fishery Bulletin, 103, 161-68.

Torcu, H., \& Aka, Z. (2000). A study on the fishes of Edremit Bay (Aegean Sea). Turkish Journal of Zoology, 24, 46-61.

Ungaro, N. (2004). Biological parameters of the brown ray, Raja miraletus, in the southern Adriatic Basin. Cybium 28, 174-176.

Wyffels, J.T. (2009). Embryonic development of chondrichthyan fishes, a review. In Y. W. Kunz, C. A. Luer \& B. G. Kapoor (Eds.), Development of non-teleost fishes (pp. 1-103). London: CRC Press.

Yıgın, C.Ç., \& İşmen, A. (2009). Length-Weight Relationships For Seven Rays From Saros Bay (North Aegean Sea). Journal of Applied Ichthyology, 25, 106-108. doi: 10.1111/j.14390426.2008.01161.x

Yıgın, C.Ç., \& Ismen, A. (2010). Age, growth, reproduction and feed of longnosed skate, Dipturus oxyrinchus (Linnaeus, 1758) in Saros Bay, the north Aegean Sea. Journal of Applied Ichthyology, 26(6), 913-919. doi: 10.1111/j.14390426.2010.01510.x

Yıgın, C.Ç., \& Ismen, A. (2012). Age, growth and reproduction of the common stingray, Dasyatis pastinaca from the North Aegean Sea. Marine Biology Research, 8(7), 644-653. doi: 10.1080/17451000.2012.659667

Yigin C.C., \& Ismen, A. (2013). Reproductive biology of spiny dogfish Squalus acanthias, in the north Aegean Sea. Turkish Journal of Fisheries and Aquatic Sciences 13 (1): 169-177. doi: 10.4194/1303-2712-v13_1_20

Yeldan, H., Avsar, D., \& Manaşırlı, M. (2009). Age, growth and feeding of the common stingray (Dasyatis pastinaca, L., 1758) in the Cilician coastal basin, northeastern Mediterranean Sea. Journal of Applied Ichthyology 25(Suppl. 1), 98102. doi: 10.1111/j.1439-0426.2008.01075.x

Zar, J.H. (1999). Biostatistical analysis, 4th edn. Prentice Hall, UpperSaddle River, NJ.

Zeiner, S.J., \& Wolf, P. (1993). Growth characteristics and estimates of age at maturity of two species of skates (Raja binoculata and Raja rhina) from Monterey Bay. In S. Branstetter (Ed.), Conservation biology of elasmobranchs. NOAA Technical Report NMFS 115 (pp. 87-99). Washington: U.S. Department of Commerce.

Zupanovic, S. (1961). Contribution à la connaissance des poisons de l'Adriatique. Acta Adriatica 9, 184. 